\title{
Acute toxicity of metronidazole and its interaction with chlorpyrifos in chicks
}

\section{D.H. Abdulrazzaq and S.M. Amin}

Department of Physiology, Biochemistry, and Pharmacology, College of Veterinary Medicine, University of Mosul, Mosul, Iraq

\section{Article information}

Article history:

Received May 02, 2020

Accepted June 12, 2020

Available online December 7, 2021

\section{Keywords:}

Metronidazole

Chlorpyrifos

Chicks

$\mathrm{LD}_{50}$

Correspondence:

D.H. Abdulrazzaq

douaa.alsanjary@uomosul.edu.iq

\begin{abstract}
Metronidazole is antimicrobial drug for human and animal use, The more characteristic side effect associated with use high dose of metronidazole is neurotoxic signs, some of these signs that recorded in animal represented by ataxia and tremor, there is limited information is available on the pharmacological profile of metronidazole in birds The aim of our study explain some of its neurological effect in chicks by its interaction with one of organophosphorus insecticide chlorpyrifos that have well-known excitatory effect on nervous system. Median Lethal Doses (LD50) of metronidazole and chlorpyrifos were determined depending on up and down method. The intraperitoneal and oral $\mathrm{LD}_{\mathbf{5 0}}$ of metronidazole were $516.9 \mathrm{mg} / \mathrm{kg}, 3061.8 \mathrm{mg} / \mathrm{kg}$ respectively. The oral LD $\mathrm{LD}_{\mathbf{5 0}}$ of chlorpyrifos was $13.705 \mathrm{mg} / \mathrm{kg}$, intraperitoneal treatment of metronidazole with Oral treatment of chlorpyrifos in ratio 1:1, 1: 0.5 , and $0.5: 1$, respectively of $L_{50}$ at the same time increased LD50 for metronidazole and chlorpyrifos and the isobolographic analysis showed that the points of interaction occurred above the diagonal line connecting between LD50 of each; while oral treatment of metronidazole and chlorpyrifos in ratio 1:0.5 LD50 at the same time decreased $\mathrm{LD}_{50}$ for metronidazole and chlorpyrifos and the point of interaction was above the diagonal line connecting between LD50 of each in conclusion we found that isobolografhic analysis for metronidazole and chlorpyrifos in different percentages and routs of treatment reveal to antagonist effect despite the similarity in the toxic signs.
\end{abstract}

DOI: $10.33899 /$ ijvs.2021.127035.1442, C2021, College of Veterinary Medicine, University of Mosul.

This is an open access article under the CC BY 4.0 license (http://creativecommons.org/licenses/by/4.0/).

\section{Introduction}

Metronidazole is a broad spectrum synthetic antimicrobial drug. That is used in veterinary medicine to treat large and small animals (1). It affected the anaerobic bacteria and protozoa, which it causes many diseases such as giardiasis, amobiasis, bowel disease, peritonitis. used also as a protective treatment after operative surgery (2).

It is a pro-drug that appears in antimicrobial effect through penetration of microorganism by passive diffusion and reduction nitro group. This leads to free radical formation that caused DNA damage and cell death in susceptible microorganisms. Metronidazole is metabolized in the liver by oxidation and by glucuronide formation. It is excreted primarily by the kidneys (3). Metronidazole can cause neurological effects. These effects usually occur if metronidazole is given at high doses or for extended periods of time (4).

Chlorpyrifos is one of the organophosphorus insecticides, widely used in veterinary medicine for insect control $(1,5)$. it kills insects through irreversible inhibition of acetylcholineastrase, which causes the accumulation of excessive acetylcholine in the synaptic cleft thus leads to over stimulation of the nervous system $(6,7)$.

It has good absorption orally and wide distribution through body tissue (8). It metabolizes in liver by 
cytochrome-p450 to chlorpyrifos-oxon, which is stronger against the nervous system than chlorpyrifos. the metabolite of chlorpyrifos is easily excreted in urine and feces (9).

Our research aims to study some neurological influence of metronidazole by interacting with chlorpyrifos, which has a well-known stimulating effect on the nervous system

\section{Materials and method}

Broiler chicks of both sexes 60 - $136 \mathrm{~g}$ were used. it had brought one day of age and put in cages of breeding with condition water food ad libitum, temperature of $30-34^{\circ} \mathrm{C}$ with constant lighting, wood shavings as floor litter, until procedure experiments age 7-14 day. The Scientific Committee of the College of Veterinary Medicine at the University of Mosul reviewed and approved the protocol of this study (10).

\section{Drugs preparation}

Metronidazole concentration $1000 \mathrm{mg} / 10 \mathrm{ml}$ used for injection was prepared by dissolve pure metronidazole in a mixture of (kollidon, lutrol, proplenglygol and distilled water) and modified to final $\mathrm{PH}$ to 4.4 by use $\mathrm{HCl}$ normality 0.1 with use light heat to obtaining complete dissolvent (11). the mixture of distilled water and propylene glygol in ratio 2:3 used as diluted for obtaining the required dose. Metronidazole suspension that used orally was prepared from mixed pure metronidazole base with tween $80(20 \%)$.

A commercial organophosphorus insecticide emulsified solution of chlorpyrifos $48 \%$ concentration (Tarkim, Turkey) diluted freshly with distilled water before dosing. The volume of administration was $10 \mathrm{ml} / \mathrm{kg}$ B.Wt. administrated orally (12).

\section{Determination of oral and intraperitoneal $\mathrm{LD}_{50}$ of metronidazole in chicks by up and down method}

Six chicks were used in determination of the oral median lethal dose $\mathrm{LD}_{\mathbf{5 0}}$ of metronidazole and their body weight ranged between 60-136 g, firstly metronidazol dosed orally at $3000 \mathrm{mg} / \mathrm{kg}$ depending on previous studies, the result was read death X or life O after 24 hour, and the amount of dose increased or decreased was constant 600 $\mathrm{mg} / \mathrm{kg}$ and repeat dosing up or down for 3 chicks after changing the result death to life and versa.

Calculate metronidazole $\mathrm{LD}_{\mathbf{5 0}}$ depending upon the diagram and equation of Dixon (13) $\mathrm{LD}_{50}=\mathrm{Xf}+\mathrm{Kd}$, in which Xf: last dose, $\mathrm{K}$ : diagram value, d: the value of dose increases or decreases.

Determination of the interpertonial median lethal dose $\mathrm{LD}_{50}$ of metronidazole used six chicks, firstly metronidazol dosed at $600 \mathrm{mg} / \mathrm{kg}$ depending on previous studies, the result was read death $\mathrm{X}$ or life $\mathrm{O}$ after 24 hours, and the amount of dose increased or decreased was constant 100 $\mathrm{mg} / \mathrm{kg}$ and repeat dosing up or down for 3 chicks after changing the result death to life and versa and calculate metronidazole LDs0 depending upon the diagram and equation of Dixon that mentioned previously

\section{Determination of the oral $L_{50}$ of chlorpyrifos in chicks by up and down method}

Eight chicks from both sex were used, firstly chlorpyrifos dosed orally at $25 \mathrm{mg} / \mathrm{kg}$ depending on previous studies, the result was read death $\mathrm{X}$ or life $\mathrm{O}$ after 24 hours, and increased or decreased in dose was constant 5 $\mathrm{mg} / \mathrm{kg}$ and repeat dosing up or down for three chicks after changing the result death to life and versa and calculate chlorpyrifos LD s0 $_{\mathbf{5}}$ depending upon the diagram and equation of Dixon as described before

\section{Interaction of interpertonial $\mathrm{LD}_{50}$ of metronidazole with oral LD $\mathrm{LD}_{50}$ of chlorpyrifos in ratio 1:1, 1:0.5 and 0.5:1}

In first group five chicks were used, treated chick firstly with $100 \%$ of interapertonail $\mathrm{LD}_{50}$ of metronidazole and directly dosed orally with $100 \%$ of oral LD50 of chlorpyrifos that obtain form first and second experiments respectively, while second group which used seven chicks, treated chick firstly with $100 \%$ of interapertonail $\mathrm{LD}_{50}$ of metronidazole and directly dosed orally with $50 \%$ of oral $\mathrm{LD}_{50}$ of chlorpyrifos, and the third group used five chicks treated chick firstly with $50 \%$ of interapertonail $\mathrm{LD}_{50}$ of metronidazole and directly dosed orally with $100 \%$ of oral LD $_{50}$ of chlorpyrifos, the results for all groups were read death X or life $\mathrm{O}$ after 24 hour, and increased or decreased in dose was constant $10 \%$ of $\mathrm{LD}_{50}$ and repeat dosing up or down for 3 chicks after changing the result death to life and versa and calculate interapertonail LD50 of metronidazole and orall of chlorpyrifos depending upon the diagram and equation of Dixon as described before. We subjected the LD50s of both metronidazole and chlorpyrifos to isobolographic analysis. We drew a straight line for the isobolographic analysis between the lethal dose of metronidazole and chlorpyrifos given to chicks either alone or in combination.

The LD 50 points of metronidazole and chlorpyrifos given alone are represented on the $\mathrm{y}$ and $\mathrm{X}$ axes, respectively. The straight diagonal line refers to the line of additively (zero interaction) at the $\mathrm{LD}_{50}$ values, and the location of the combination points on the left (below)and right (above) side of the additive line refer to synergistic and antagonistic interactions, respectively.

The interaction index was calculated using the equation $\mathrm{da} / \mathrm{Da}+\mathrm{db} / \mathrm{Db} \mathrm{Da}$ and $\mathrm{Db}$ are the individual LDsos for metronidazole and chlorpyrifos respectively whereas da and $\mathrm{db}$ are their combined LD50s. An interaction index of 1 means additivity (no interaction), < 1 synergy, and $>1$ antagonism (14). 


\section{Interaction of oral $\mathrm{LD}_{50}$ of metronidazole with oral $\mathrm{LD}_{50}$ of chlorpyrifos at ratio 1:0,5}

five chicks from both sex were used, firstly metronidazole dosed orally at $100 \%$ of $\mathrm{LD}_{50}$ and directly dosed orally with $50 \%$ of oral LD50 of chlorpyrifos, the result read death $\mathrm{X}$ or life $\mathrm{O}$ after 24 hour, and increased or decreased in dose was constant $10 \%$ of LD50 and repeat dosing up or down for 3chicks after changing the result death to life and versa and calculate orall LD50s of metronidazole and chlorpyrifos depending upon the diagram and equation of Dixon as described above. We subjected the LD50s of both metronidazole and chlorpyrifos to isobolographic analysis also the interaction index was calculated $(14,15)$.

\section{Results}

Determination of the oral and intraperitoneal LD50 of metronidazole in chicks by up and down method

The acute (24 houre) oral $\mathrm{LD}_{50}$ value of metronidazole was $3061,08 \mathrm{mg} / \mathrm{kg}$ body weight and intraperitoneal $\mathrm{LD}_{50}$ value was 516, $9 \mathrm{mg} / \mathrm{kg}$ body weight (Table 1). with appearance of the toxic signs which represented by quiet, tease feathers, close the eye, ataxia, increase defecation, recumbency and eventually death.
Determination of the oral median lethal dose $L_{50}$ of chlorpyrifos in chicks by up and down method

The acute oral $\mathrm{LD}_{50}$ value of chlorpyrifos in chicks was $13,705 \mathrm{mg} / \mathrm{kg}$ body weight (Table 2), and the signs of toxicity were tremor, salivation, lacrimation, dyspnea, slouch wing, stretchon or both feet, recumbency, finally dead in high toxic dose.

Interaction of interpertonial $\mathrm{LD}_{50}$ of metronidazole with oral $L D_{50}$ of chlorpyrifos in ratio 1:1, 1:0.5 and 0.5:1

The intraperitoneal $\mathrm{LD}_{50 \mathrm{~s}}$ of metronidazol were 552.312 ; $677.04 ; 292.895 \mathrm{mg} / \mathrm{k}$ g body weight and oral LD 50 s of chlorpyrifos were $14.6306 ; 10.932 ; 13.3085 \mathrm{mg} / \mathrm{kg}$ body weight, when treated in ratio 1:1 1:0, 5 and $0,5: 1$ respectively (Table 3), isobolographic analysis of these LD 50s for metronidazole and chlorpyrifos (either alone or in combination) revealed that combined treatment has antagonist effect (Figure 1).

This antagonist effect was established by the location of the points that represent the combined $\mathrm{LD}_{50 \mathrm{~s}}$ of metronidazole and chlorpyrifos above the diagonal lines that connect their LD50s when treated alone. Furthermore, the calculated interaction index was $2.136,2.107,1.49$ in ratio $1: 1,1: 0.5,0.5: 1$, respectively.

Table 1: Determine LD50 of metronidazole i.p and p.o by up-down method

\begin{tabular}{lcc}
\hline \multirow{2}{*}{ Measurement } & \multicolumn{2}{c}{ Result } \\
\cline { 2 - 3 } & IP & PO \\
\hline Median lethal dose & $516.9 \mathrm{mg} / \mathrm{kg}$ & 3061.8 \\
Range doses & $400-600$ & $3000-3600$ \\
First dose & 600 & 3000 \\
Last dose & 500 & 3600 \\
Increase and decrease in the dose & 100 & 600 \\
Number of chicks & 6 (XXOOXO) & 6 (XXOOOX) \\
Time appear signs & $7-20$ min. & $10-25$ min. \\
Toxicity signs & Quite, tease feathers, close eye, & Quite, tease feathers, close eye, ataxia, \\
& recumbency, death. & increase defecation, recumbency death \\
\hline
\end{tabular}

O: chick still life during 24 hours, $\mathrm{X}$ : chick dead during 24 hours.

Table 2: determination oral LD50 of chlorpyrifos by up and down method

\begin{tabular}{ll}
\hline Measurement & Result \\
\hline Median lethal dose & $13.705 \mathrm{mg} / \mathrm{kg}$ \\
Range dose & $25-5$ \\
First dose & 25 \\
Last dose & 10 \\
Increase and decrease in the dose & 5 \\
Number of chicks & 8 (XXXXOXOX) \\
Time appear signs & $7-10$ minute \\
Toxicity signs & Quite, salivation, lacrimation diarrhea, tremor, dyspnea, slouch wing, stretch on or \\
& both feet, convulsion, death \\
\hline O: chick still life during 24 hours, X: chick dead during 24 hours.
\end{tabular}


Table 3: determine LD50 of metronidazole i.p and chlorpyrifos p.o at ratio 1:1 1:0, 5 0, 5:1 by up and down method

\begin{tabular}{lccccc}
\hline Groups & LD $50 \mathrm{mg} / \mathrm{kg}$ & First dose & Last dose & No. of chicks & Result after 24h \\
\hline $\mathrm{M}$ & 516.9 & 600 & 400 & 6 & XXOOXO \\
Ch & 13.705 & 25 & 5 & 8 & XXXXOXOX \\
M+ Ch $1: 1$ & $552.312+14.6306$ & $516.9+13.705$ & $618.9+16.305$ & 5 & XOOOX \\
M+ Ch $1: 0.5$ & $677.04+10.932$ & $516.9+6.8525$ & $720.9+12.05$ & 7 & OOOXOOX \\
M+ Ch $0.5: 1$ & $242+13.3085$ & $258.54+13.705$ & $258.4+13.705$. & 5 & XOOXX \\
\hline
\end{tabular}

O: chick still life during 24 hours, X: chick dead during 24 hours, M: Metronidazole, Ch: Chlorpyrifos.

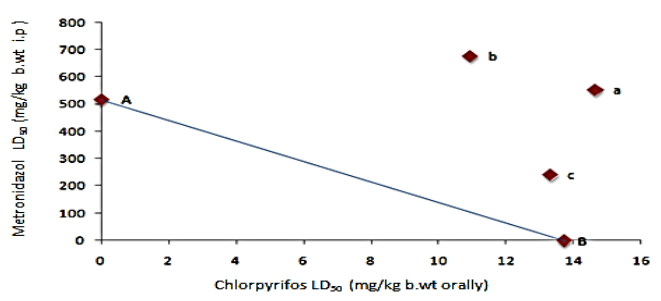

Figure 1: Isobolographic representation of the interaction of metronidazol and chlorpyrifos at $\mathrm{LD}_{50}$ level in chicks $\mathrm{A}, \mathrm{B}$ points represent the LD50 of metronidazol, chlorpyrifos respectively when given alone whereas a,b,c points represent isolethal combination of metronidazol and chlorpyrifos in rate of $\operatorname{LD}_{50} 1: 1,1: 0.5,0.5: 1$, respectively.
Interaction of oral $\mathrm{LD}_{50}$ of metronidazole with oral $\mathrm{LD}_{50}$ of chlorpyrifos in ratio 1:0, 5

When treated metronidazole and chlorpyrifos orally at the same time in ratio 1:0, 5 of $\mathrm{LD}_{50}$ the values of $\mathrm{LD}_{50 \mathrm{~s}}$ became $3036.1 \mathrm{mg} / \mathrm{kg}$ body weight; $6.73742 \mathrm{mg} / \mathrm{kg}$ body weight respectively (Table 4). Isobolographic analysis of these LD50s for metronidazole and chlorpyrifos (either alone or in combination) revealed that combined treatment has antagonist effect (Figure 2), this antagonist effect was established by the location of the points that represent the combined LD50s of metronidazole and chlorpyrifos above the diagonal lines that connect their LDsos when treated alone. Furthermore, interaction index was 1.482 (an index of $>1$ indicates antagonism).

Table 4: Determination of oral $\mathrm{LD}_{50}$ of metronidazole and chlorpyrifos at ratio 1:0, 5 by up and down method

\begin{tabular}{lccccc}
\hline Groups & LD $50 \mathrm{mg} / \mathrm{kg}$ & First dose & Last dose & No. of chicks & Result after 24h \\
\hline M & 3061.8 & 3000 & 3600 & 6 & XXOOOX \\
Ch & 13.705 & 25 & 5 & 8 & XXXXOXOX \\
M+ Ch 1:0.5 & $3036.0876+6.7373$ & $3061.8+6.8525$ & $3061.8+6.8525$ & 5 & XOXOO \\
\hline
\end{tabular}

O: chick still life during 24 hours, X: chick dead during 24 hours, M: Metronidazole, Ch: Chlorpyrifos.

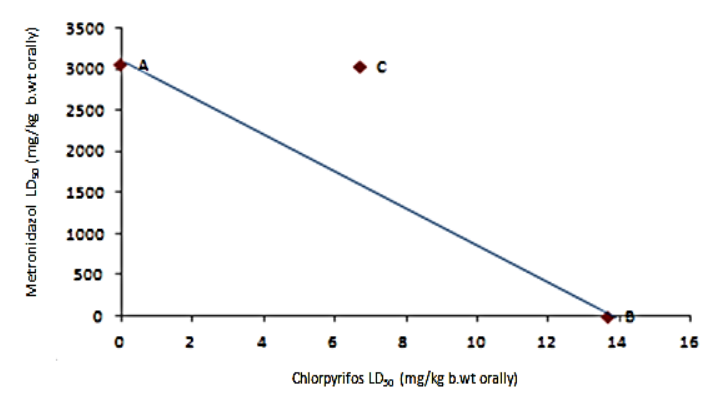

Figure 2: Isobolographic representation of the interaction of metronidazol and chlorpyrifos at LDso level in chicks A, B points represent the LDs0 of metronidazol, chlorpyrifos respectively when given alone whereas $\mathrm{C}$ point represent isolethal combination of metronidazol and chlorpyrifos in rate of $\mathrm{LD}_{50}$ 1:0.5.

\section{Discussion}

Metronidazole is widely used in veterinary and human medicine, used against protozoa, gram positive and gram negative anaerobic bacterial infection, metronidazole has the ability to cross the blood brain barrier resulting in neurotoxicity effects (16). The more characteristic signs associated with use high dose in animal represented by ataxia, tremor and weakness (17). The acute oral and intraperitoneal toxicity for metronidazole that determined in chicks at present research corresponding well with previous study (18) and the clinical signs represented by tease feather, close eyes, increase defecation, ataxia recumbent and death metronidazole classify as moderately toxic according to this result. The acute oral $\mathrm{LD}_{50}$ of chlorpyrifos in chick was $13.705 \mathrm{mg} / \mathrm{kg} \mathrm{B}$.Wt, in the previous study the LD50 of chlorpyrifos in chicks was $18.14 \mathrm{mg} / \mathrm{kg}$ B.Wt and some reported $\mathrm{LD}_{50}$ ranged $25-35 \mathrm{mg} / \mathrm{kg}$ B.Wt (19) we can attributed this different to variation of chlorpyrifos origin, as well as the solvents, the intermediate vehicles, and the 
concentration of the active ingredient in the formula as well as laboratory condition, and animal breed variation (20). It is worthy of mention that chlorpyrifos consider as highly toxic in birds and poultry, the toxic signs represented by cholinergic toxicity syndrome like salivation, defecation, muscle spasm, dispense and death due to a penea.

When given with metronidazole i.p and chlorpyrifos p.o at the same time and in different ratio $1: 1,1: 0.5,0.5: 1$ in spite of using of double toxic doses that must cause increase the severity of the toxic signs, as well as increased in the death percentage, the results of these ratios increased $\mathrm{LD}_{50}$ s for metronidazole and chlorpyrifos that means decrease in toxicity for both. Isobolographic analysis of these $\mathrm{LD}_{50 \mathrm{~s}}$ for metronidazole and chlorpyrifos revealed that combined treatment interpretation of antagonist effects these antagonist effect was established by the location of the points represent the combined $\mathrm{LD}_{50 \text { s }}$ of metronidazole and chlorpyrifos above the diagonal lines that connect their LD50s when given alone. Further, the calculated interaction index when treated metronidazole i.p and chlorpyrifos p. o. in ratio $1: 1,1: 0,5,0,5: 1$ were $2.136,2.107,1.49$ respectively. drug interaction are caused by either pharmacodynamic or pharmacokinetic interaction (21), we can contributed pharmacodynamic interaction to decreased connect of chlorpyrifos with $\mathrm{AChE}$ due to connected metronidazole with AChE In competitive and reversible shape as same as mechanism of a reversible cholinergic medication like physostigmin, spontaneous recovery from metronidazol neurotoxicity may confirm this theory As it will explain devolution of metronidazole toxicity compare with chlorpyrifos (22), pharmacokinetic interaction may cause by inhibit effect of metronidazole liver enzyme caused diminished transformation of chlorpyrifos to active form to became less toxic $(23,24)$, Moreover, metronidazole basic drug distributed better than acidic chlorpyrifos which make its effect greater than chlorpyrifos which may be undergo from ion trapping in plasma (25). to more confirmation type of interaction we given metronidazole and chlorpyrifos orally in ratio 1:0.5 from LD50 respectively the results of interaction were 3036.8, $6.733 \mathrm{mg} / \mathrm{kg}$ B.Wt in spite of decrease $\mathrm{LD}_{50}$ for both metronidazole and chlorpyrifos the isobolographic analysis still reveal to antagonism and the interaction index confirm above results which it was 1.482 . we can contribute decrease $\mathrm{LD}_{50}$ to rapid oral absorption of chlorpyrifos by GIT compare with metronidazole $(3,8,25)$ subsequently apply their effect rapidly.

\section{Conclusion}

In conclusion, the toxicity of metronidazol and chlorpyrifos in chicks are decreased when using at the same time in different ratios and route of administration. Further studies must be done to evaluate real clinical significance of these drug-drug interactions.

\section{Acknowledgement}

This study was supported by the College of Veterinary Medicine, University of Mosul, Mosul, Iraq.

\section{Conflict of interest}

Researchers declare no conflict of interests of the manuscript.

\section{References}

1. Mark GP. Veterinary drugs. $4^{\text {th }}$ ed. New York: Elsevier; 2016. 524$527 \mathrm{p}$.

2. Plumb DC. Veterinary drug hand book. $6^{\text {th }}$ ed. Iowa: Black Well;2008. 2610-613 p.

3. Leitsch D. A review on metronidazole: An old warhorse in antimicrobial chemotherapy. Parasitol. 2019;146(9):1167-1178. DOI: 10.1017/S0031182017002025

4. Li L, Tang $\mathrm{X}$, Li W, Liang S, Zhu Q, Wu MA. Case of methylprednisolone treatment for metronidazole-induced encephalopathy. BMC Neurol. 2019;19(1):49. DOI: 10.1186/s12883019-1278-6

5. Yıldırım E, Baydan E, Kanbur M, Kul O, Çnar M, Ekici H, Atmaca $\mathrm{N}$. The effect of chlorpyrifos on isolated thoracic aorta in rats. Biomed Res Int. 2013;37:51. DOI: 10.1155/2013/376051

6. Yahia D, Ali MF. Cytogenetic and genotoxic effects of penconazole and chlorpyrifos pesticides in bone marrow of rats. J Adv Vet Res. 2019;9(2):29-38. [available at]

7. Ahir UN, Vyas TK, Gandhi KD, Faldu PR, Patel KG. In vitro efficacy for chlorpyrifos degradation by novel isolate tistrella sp. auc10 isolated from chlorpyrifos contaminated field. Curr Microbial. 2020;77:2226-2232 DOI: 10.1007/s00284-020-01998-1

8. California Environmental Protection Agency. Final toxic air contaminant evaluation of chlorpyrifos. 2018. [available at]

9. Eaton DL, Daroff RB, Autrup H, Bridges J, Buffler P, Costa LG, Coyle J, McKhann G, Mobley WC, Nadel L, Neubert D. Review of the toxicology of chlorpyrifos with an emphasis on human exposure and neurodevelopment. Crit Rev Toxicol. 2008;38(2):1-2. DOI: 10.1080/10408440802272158

10. Al-Abdaly YZ, Saeed MG, Al-Hashemi HM. Effect of methotrexate and aspirin interaction and its relationship to oxidative stress in rats. Iraqi J Vet Sci. 2021;35(1):151-156. DOI: 10.33899/ijvs.2020.126490.1335

11. Buhlar V. Generic drug formations. $2^{\text {nd }}$ ed. Germany: Luwigshafen; 1998. 233p.

12. Ahmed AS. Change in acetylcholine activity and some blood parameters in adult sheep dipped in deltamethrin. Iraqi $\mathbf{J}$ Vet Sci. 2020;35(2):301-304. DOI: 10.33899/ijvs.2020.126813.1385

13. Dixon WJ. Efficient analysis of experimental observations. Ann Rev Pharmacol Toxicol. 1980;20:441-462.

14. Puig MM, Warner W, Pol O. Intestinal inflammation and morphine tolerance alter the interaction between morphine and clonidine on gastrointestinal transit in mice. Anesthesiol. 2000;93(1):219-230. DOI: $10.1097 / 00000542-200007000-00033$

15. Al-Kshab AA, Yehya OQ. Determination of the lethal concentration $50 \%\left(\mathrm{LC}_{50}\right)$ of lead chloride and its accumulation in different organs of Gambusia affinis fish. Iraqi J Vet Sci. 2021;35(2):361-367 DOI: 10.33899/ijvs.2020.126853.1401

16. Chaturvedi S, Malik MY, Rashid M, Singh S, Tiwari V, Gupta P, Shukla S, Singh S, Wahajuddin M. Mechanistic exploration of quercetin against metronidazole induced neurotoxicity in rats: Possible role of nitric oxide isoforms and inflammatory cytokines. Neurotoxicol. $\underline{10.1016 / j . \text { neuro.2020.03.002 }}$ 
17. Hajek I, Simerdova V, Vavra M, Agudelo CF. Toxic encephalopathy associated with high-dose metronidazole therapy in a dog: A case report. Vet Med. 2017;62(2):105-110. DOI: 10.17221/264/2015VETMED

18. Hussan SMA. Toxicity of metronidazole in chicks and it's distribution in tissue with some concomitant biochemical changes [Master' $\mathrm{s}$ thesis]. Mosul: College of Veterinary Medicine, University of Mosul; $2010.52 \mathrm{p}$

19. Al-Badrany YA, Mohammad FK. Effects of acute and repeated oral exposure to the organophosphate insecticide chlorpyrifos on openfield activity in chicks. Toxicol. 2007;174(1-3):110-116. DOI: 10.1016/j.toxlet.2007.09.001

20. Swiergosz R, Molenda P, Halota A. Effects of chemical and thermal stress on acetylcholinesterase activity in the brain of the bank vole Myodes glareolus. Ecotoxicol Environ Saf. 2014;106:204-212. DOI: 10.1016/j.ecoenv.2014.04.021

21. Miranda V, Fede A, Nobuo M, Ayres V, Giglio A, Miranda M, Riechelmann RP. Adverse drug reactions and drug interactions as causes of hospital admission in oncology. J Pain Symptom Manage. 2011;42(3):342-353. DOI: 10.1016/j.jpainsymman.2010.11.014

22. Nguyen TT, Armengol C, Wilhoite G, Cumpston KL, Wills BK. Adverse events from physostigmine: An observational study. Am J Emerg Med. 2018;36(1):141-142. DOI: 10.1016/j.ajem.2017.07006

23. Sparling DW, Fellers G. Comparative toxicity of chlorpyrifos, diazinon, malathion and their oxon derivatives to larval Rana boylii. Environ Pollut. 2007;147(3):535-539. DOI: 10.1016/j.envpol.2006.10.036

24. Mustafa KA, Al-Baggou BKh. Toxicological and neurobehavioral effects of chlorpyrifos and deltamethrin insecticides in mice. Iraqi $\mathbf{J}$ Vet Sci. 2020;34(1):189-196. DOI: 10.33899/ijvs.2019.125738.1144

25. Rodgers T, Rowland M. Physiologically based pharmacokinetic modelling 2: Predicting the tissue distribution of acids, very weak bases, neutrals and zwitterions. J Pharm Sci. 2006;95(6):1238-1257. DOI: $\underline{10.1002 / j p s .20502}$

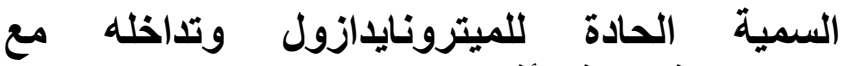 الكلوربايرفوس في أفراخ الاجاج دعاء هيثم عبد الرزاق و سوسن محمد أمين}

فرع الفسلجة والكيمياء الحياتية والأدوية، كلية الطب البيطري جامعة

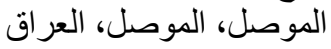

الخلاصة

الميترونيدازول هو دواء مضاد للميكروبات للاستخدام البشري

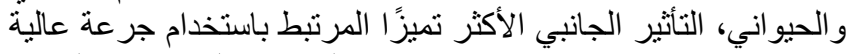

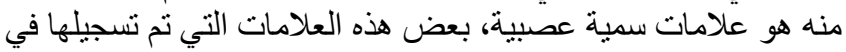

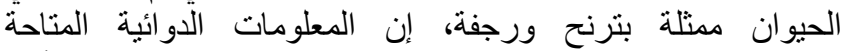

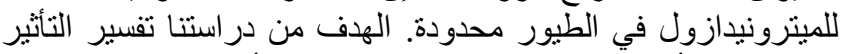

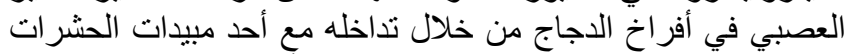

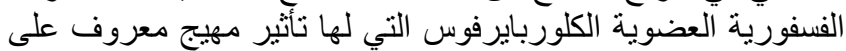

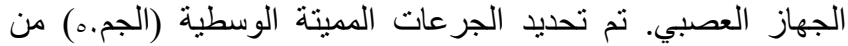

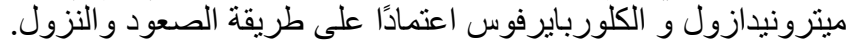

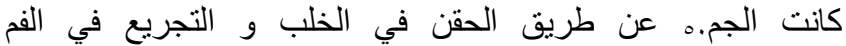

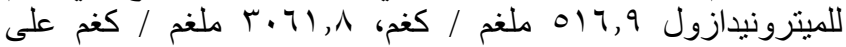

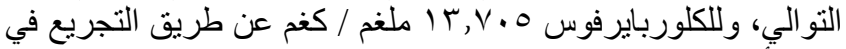

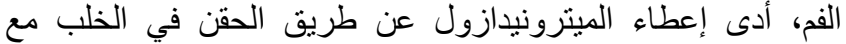

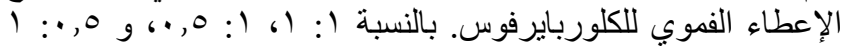

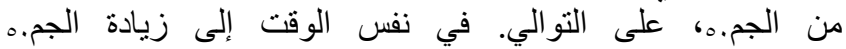
للميترونيدازول و الكلوربايرفوس وقد اظهر التحليل البياني وقوع نقاط

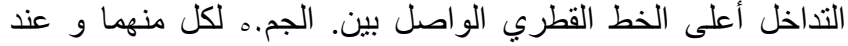

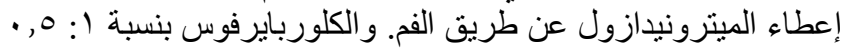

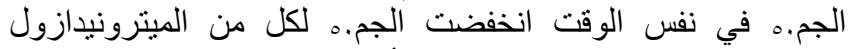

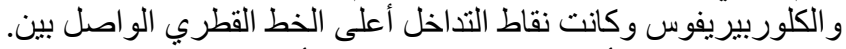

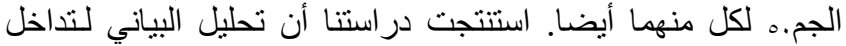
الميترونيدازول الكلوربايرفوس بكل النسب وطرق الإعطاء المختلفة تكثف عن التأثير المضاد على الرغم من التثابه في العلامات السامة لكليهما. 